DOI: https://doi.org/ 10.25100/iyc.v20i2.6354

INGENIERÍA AMBIENTAL

\title{
Determinación de relaciones nivel - caudal simple o compleja en un río. Caso del río Cauca
}

\section{Determination of simple and complex water level - discharge relationship in a river. Case of the Cauca River}

\author{
Carlos A. Ramírez ${ }^{1} \S$, Yesid Carvajal ${ }^{1}$, Ricardo A. Bocanegra ${ }^{1}$, María C. Sandoval ${ }^{2}$ \\ ${ }^{1}$ Escuela de Ingeniería de los Recursos Naturales y del Ambiente-EIDENAR, \\ Universidad del Valle. Cali, Colombia. ${ }^{2}$ Dirección Técnica Ambiental, Corporación \\ Autónoma Regional del Valle del Cauca CVC. Cali, Colombia. \\ carlos.ramirez@correounivalle.edu.co,yesid.carvajal@correounivalle.edu.co, \\ ricardo.bocanegra@correounivalle.edu.co,maria-clemencia.sandoval@cvc.gov.co
}

(Recibido:25 de octubre de 2017- Aceptado:23 de mayo de 2018)

\section{Resumen}

La relación nivel de agua - caudal en un río, denominada también curva de calibración, es de gran utilidad práctica pues permite estimar los caudales a partir de los niveles registrados en una estación hidrométrica. Cuando el régimen es aproximadamente permanente a cada nivel le corresponde un caudal (relación simple). No obstante, frecuentemente diferentes circunstancias pueden generar una relación compleja entre los niveles y los caudales, donde un caudal puede estar relacionado con dos niveles de agua y viceversa. En el presente estudio se determinaron las curvas de calibración simple y compleja en la estación La Balsa, localizada $27 \mathrm{~km}$ aguas abajo del embalse de Salvajina (río Cauca, Colombia). La curva simple se calculó mediante el método logarítmico, el cual permite identificar las características del tipo de control que determina la relación nivel - caudal. La curva compleja se calculó según el método de almacenamiento por unidad de tasa de cambio en los niveles de agua, el cual permite ajustar el caudal obtenido en la curva nivel - caudal para régimen permanente considerando un almacenamiento debido al cambio en el nivel. Los resultados muestran diferencias importantes en los caudales estimados por medio de las dos relaciones. Al aplicar las dos curvas de calibración para una creciente moderada (01/01/1999) se encontraron diferencias hasta de un 19\% entre los caudales calculados. En consecuencia, para establecer la curva de calibración nivel-caudal apropiada se debe realizar un análisis riguroso de las condiciones del flujo, tanto en la estación hidrométrica como aguas arriba y aguas abajo de ella.

Palabras clave: curva de calibración; relación simple; relación compleja; río Cauca

\begin{abstract}
The stage - discharge relationship in a river, or rating curve, is very useful because it allows calculating the discharges from measured stages or water levels in a gauge station. For a nearly steady regime a discharge corresponds to a water level (simple relationship). However, frequently different circumstances can originate a complex relation between waters levels and discharges and then a discharge can be referred to two water levels and vice versa. In this study, simple and complex rating curves were determined in La Balsa hydrometric station, located $27 \mathrm{~km}$ downstream of Salvajina reservoir (Cauca river, Colombia). The simple curve was calculated by applying the logarithmic method, which allows identifying the characteristics of the type of control that determines the water level - discharge relationship. The complex curve was calculated by using the method of storage per unit rate of variation in water levels, which allows adjusting the discharge obtained with the rating curve for steady flow considering a storage due to the variation in the level. The results show significant differences in the estimated discharges through the two relationships. By applying the two rating curves for a moderate flood (01/01/1999) differences up to 19\% were estimated between both calculated discharges. In consequence, in order to get the appropriated rating curve it should to carry out a rigorous analysis of the flow conditions on the river reaches of the hydrometric station.
\end{abstract}

Keywords: Rating curve, simple relationship, complex relationship, Cauca river. 


\section{Introduccion}

Stage - discharge rating curves in a river define or establish the relationship between stages or water levels $(\mathrm{H})$ and discharges $(\mathrm{Q})$ and are very useful because they allow estimating discharge flows using level records in a hydrometric station. These curves can be simple or complex depending on the flow regime and the characteristics of the stretch of river under study. Most of the rating curves are simple and to determine them gaugings data are required (water levels and discharges). Numerous studies can be found in the literature for the determination of rating curve considering different methods (graphs, statisticals, neural networks, etc.) and their extrapolation for high water levels (due to the difficulties and risks inherent to the measurements for these conditions) (Bhattacharya and Solomatine, 2000, Deka and Chandramouli, 2003, Sivapragasam and Muttil, 2005, Kim et al., 2016, Barbetta et al., 2017). Schmidt and Yen (2001) examined the relationships of rating curve in open channels based on the basic hydrodynamics of non-uniform non-steady flow and identified terms in the Saint-Venant equations that should be considered in the rating curves. León et al. (2006 $\mathrm{a}, \mathrm{b})$ derived the level - discharge relationship of 21 virtual measuring stations in the River Negro (Amazon), using satellite altimetric measurements; the discharges were calculated using a routing discharge model based on Muskingum - Cunge.

When there is a non-stationary regime (due to the operation of a reservoir upstream, for example) or when the slope of the free surface of the water is variable (due to the backwaters produced by discharges of a tributary located downstream or due to a reservoir) there is no simple relationship between levels and discharges, so a complex rating curve must be established (Kennedy, 1984). In this case, discharges must be related to water levels and another additional variable, such as the rate of variation in water levels in a gauging station or the slope of the free surface of the water. Authors such as Kennedy (1984), Aldana (2002), Lohani et al. (2006), Sadeghi et al. (2008) and among others, describe methods for determining complex rating curves. Bhattacharya and Solomatine (2005),
Ajmera and Goyal (2012), Kashani et al. (2015) and Zeroual et al. (2016) use artificial neural networks in the estimation of this type of curves.

The operation of the Salvajina reservoir for power generation imposes most of the time a very dynamic regime in the Cauca river, causing downstream discharges higher than those of the steady state when the water level rises and lower when the water level drecreases (CVC - Universidad del Valle, 2000). This produces a storage in the section that causes a loop in the Level - Discharge relationship, which is a phenomenon known as hysteresis. Based on the available field information in the Corporación Autónoma del Valle del Cauca, CVC, in the period 1999-2004, simple and complex rating curves were determined and compared with each other in the La Balsa station, located about $27 \mathrm{~km}$ downstream of the Salvajina reservoir (CVC - Universidad del Valle, 2005a). In this gauging station the river has an approximate width of $65 \mathrm{~m}$ and a depth to bank full of almost 3.5 $\mathrm{m}$, the slope of the left bank is pronounced and that of right margin relatively smooth (CVC - Universidad del Valle, 2005b); During the gaugings, which are carried out by suspension from a cable car, a rapid variation of river levels is presented due to the regulatory effect of the Salvajina reservoir (Figure 1). Discharges were calculated for flood of January 01 of 1999 using simple and complex rating curves, with differences of up to $19 \%$ between the estimated discharges using each of these curves. Several authors have examined the uncertainties in the rating curves and uncertainties resulting from discharges records (Clark et al., 2000; Claps et al., 2003; Petersen and Reitan, 2008; Jalbert et al, 2011; Juston et al., 2013).

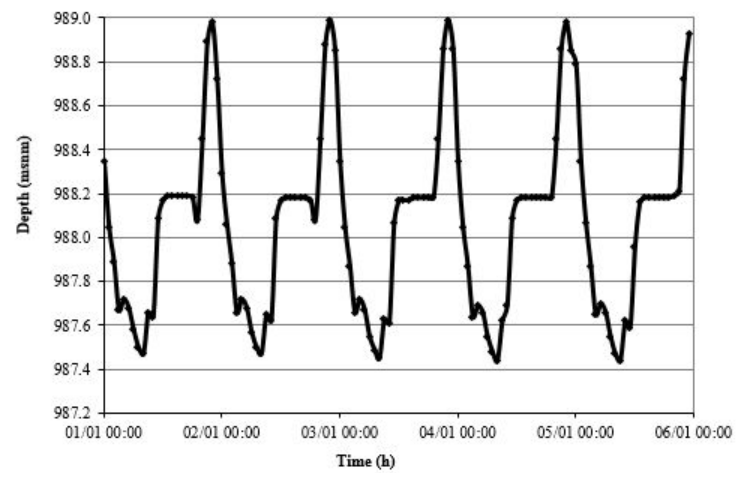

Figure 1. Variation of the water level in La Balsa station. Period 1 to 5 January 51998 
The study was developed following and applying the methods and procedures of the ISO Standards for the elaboration of rating curves Level - Discharge (ISO, 1992, ISO, 1998) and the Techniques of Water Resources Investigations of the U. S. Geological Survey. (Kennedy, 1984), as well as other national and international guides. (Pérez, 1969, Aldana, 2002).

\section{Methodology}

\subsection{Simple Rating Curve}

Simple rating curves, the most common in practice, relate discharges only to stages in a hydrometric station, in steady or permanent regime. This relationship can be determined after making numerous measurements of levels and discharges covering a wide range of levels to define a continuous curve. There are different methods for the elaboration of simple rating curves, such as: graphic, hydraulic equations (Manning and Chezy) and analytical (logarithmic, parabolic and the three curves). In the hydrometric stations of the Cauca River (Reach Salvajina - La Virginia), simple rating curves were determined considering all these methods (CVC-Universidad del Valle, 2005a) and no appreciable differences were found between them.

In this study, the logarithmic method was adopted to determine the simple rating curve because it has the following advantages: (i) it allows identifying the type of control (section or channel) that determines the relationship Stage - Discharge for a certain range of levels; (ii) in a logarithmic scale graph it is easier to establish if the control type changes from a certain level and, therefore, to determine with better approximation the shape, curvature, position and tendency of the rating curve for the different ranges of levels; (iii) it allows plotting transition curves in those ranges where changes occur in the types of controls; and, (iv) it allows establishing the effective level of zero discharge.

If the section of a river can be approximated to a known geometric figure, the discharge in the section can be expressed as:

$$
Q=C\left(H-H_{0}\right)^{n}
$$

where: $\mathrm{Q}=$ discharge $\left(\mathrm{m}^{3} / \mathrm{s}\right), \mathrm{H}=$ measured water level (m), $\mathrm{H}_{0}=$ effective level of discharge zero (m), $\mathrm{C}=$ coefficient (constant), $\mathrm{n}=$ exponent (constant).

This expression is equivalent to the following equation:

$$
\log Q=\log C+n \log \left(H-H_{0}\right)
$$

Which represents the equation of a straight line of slope $\mathrm{n}$ and intercept $\log \mathrm{C}$.

The effective level of discharge zero $\left(\mathrm{H}_{0}\right)$ is the water level that, when it is subtracted of the water levels obtained during gaugings, will produce a straight line in the relation Level - Discharge in a logarithmic scale graph (ISO 1100-2, 1998). Generally $\mathrm{H}_{0}$ is not known and can be found by trial and error, assuming different values of $\mathrm{H}_{0}$ and plotting $\log \mathrm{Q}$ vs. $\log \left(\mathrm{H}-\mathrm{H}_{0}\right)$; the final value of $\mathrm{H}_{0}$ is the one that allows obtaining the best fit to a straight line. Statistically, the correct value of $\mathrm{H}_{0}$ will be the one for which the coefficient of determination of the regression is maximum. The measured water level minus the effective level of discharge zero represents the effective depth of flow in the control $\left(\mathrm{H}-\mathrm{H}_{0}\right)$.

\subsection{Complex Rating Curve}

The Stage - Discharge relationship can be affected by different circumstances and events. An existing reservoir downstream of a hydrometric station can originate backwaters upstream, and to submerge totally or partially the flow control of the station and, therefore, to invalidate the Level - Discharge relationship. Likewise, a tributary discharging downstream or within the flow control section of the station can generate variable backwaters in the main channel, which can submerge the control and affect the stage - discharge relationship. Also, the operation of a dam for purposes of energy generation imposes conditions of dynamic or non - stationary regime downstream in the river, resulting in an effect known as "hysteresis" or "loop curve". Different authors, such as, Lohani et al. (2006), Braca (2008), Sadeghi et al. (2008) and Birgand (2013) deal with this phenomenon. 
When the water levels rise, an accelerated flow occurs and the velocities and discharges are higher; on the other hand, when the levels decrease, there is a deceleration of the flow that reduces the velocity of the water. Therefore, the actual discharge for a given water level will be greater than the "normal" discharge (taken from the simple rating curve) when the water level rises and the actual discharge will be lower than the "normal" discharge when the water level decreases. In all these cases, in which the free surface of the water and its gradient are variable and there is no simple relationship between the levels and the discharges, complex rating curves must be developed.

A calibration loop can be plotted by joining the consecutive discharge data during a flood. If the complex rating curve has already been established, the loop for each flood can be obtained (without discharge measurements) by joining the successive points of instantaneous levels and the corresponding calculated discharge of that curve. Generally, two types of auxiliary curves are used in the determination of the rating curve: (i) $\mathrm{H}$ vs. $\Delta \mathrm{Q} / \mathrm{J}$ (effect of storage by rate of variation in the level), which treats the loop of the rating curve as a simple storage phenomenon; and (ii) $\mathrm{H}$ vs. 1/ USc, which considers the magnitude of the loop to the velocity of the flow waves (U) and to the slope of the water surface at constant discharge (Sc). This last method was not applied in the La Balsa station, because there is no auxiliary topographic stadia rod near the station that allows determining the slope of the free surface of the water.

\section{Method of storage per unit of water level vari- ation rate $(\Delta Q / J)$}

The main components in this method are a Level - Discharge curve for steady regime and a storage curve. The actual discharge is calculated by adding a correction per storage to the discharge obtained from the Level - Discharge curve for steady regime. The storage correction is the value obtained from the storage curve multiplied by the rate of change in the water level. The equation to determine the discharge in non-steady regime is the following:

$$
Q_{m}=Q_{r}+\left(\frac{\Delta Q}{J}\right) \times J
$$

where: $\mathrm{Q}_{\mathrm{m}}=$ Measured discharge, $\mathrm{Qr}=$ Discharge read from the rating curve, $\Delta \mathrm{Q}=$ Difference between the actual discharge measured and the discharge read from the rating curve, $\mathrm{J}=$ Rate of variation in the water level during the gauging.

The method of variation rate of water level does a correction of the discharge in the river in accordance with the storage that occurs during a flood. This correction is achieved by constructing two curves: a Level - Discharge curve for steady regime condition and an auxiliary storage curve level $-\Delta \mathrm{Q} / \mathrm{J}$.

The rating curve is obtained by trial and error, starting with a curve plotted very close to the measurements made during the condition of steady or quasi- steady regime. The difference between each measured discharge and the discharge read of the previous curve for steady state $(\Delta \mathrm{Q})$ is divided by the rate of change in the water level during the gauging (J) and plot against the water level in another graph. The storage curve represents the storage correction due to the variation rate over time of the water level and is based on these plotted points. Each measured discharge is adjusted to steady regime conditions (corrected by storage effect) using the storage curve. The process is repeated until refinement of the rating curve or storage curve is not possible.

The curve $\Delta \mathrm{Q} / \mathrm{J}$ must be plotted by giving different weights to the plotted points [(Qm - Qr) / J]. Those points based on measured flows, whose rates of variation in water levels during gauging $(\mathrm{J})$ are high have a greater weight and, therefore, the storage curve should be plotted close to those points.

The general shape of the storage curve $\Delta \mathrm{Q} / \mathrm{J}$ is predictable. Generally the storage curve starts with a value $\Delta \mathrm{Q} / \mathrm{J}$ equal to zero for the water levels where the control of low waters is submerged, it increases until reaching a maximum value at a level close to bankfull and again it becomes zero when the flow above the bank contains more than half of the discharge. The curve should be as gradual or smooth as the data allow. 
The procedure to determine the complex rating curve is as follows:

1. Prepare the field data and tabulate the following information: indicator or number of the gauging (Column 1), measured water level ( $\mathrm{H}$, Column 2), gauged discharge (Qm, Column 3) and hourly change rate of the water level during the gauging (J, Column 4).

2. Graph the field data of Water Level against Discharge in log-log paper.

3. Plot a first curve Level - Discharge: the curve must be plotted very close to the points corresponding to the steady regime, to the left of the gaugings carried out during the ascending water levels and to the right of the descending water levels. Then skip to step 6 for the first calculation or trial.

4. Graph the data of level against the adjusted discharge (Qaj) (recorded in Column 10).

5. Plot the curve Level Vs. Adjusted Discharge: this curve must average the points plotted in point 4 , as much as possible.

6. Read the discharges values of the curve plotted in step 3 (first trial) or in step 5 (subsequent trials). These discharges are recorded in Column 5 (Qr)

7. Calculate and record it in Column $6 \Delta \mathrm{Q}=\mathrm{Qm}-$ Qr, that is, subtract Column 3 minus Column 5. If $0.03>\mathrm{J}>-0.03(\mathrm{~m} / \mathrm{h})$, write a hyphen (-).

8. Calculate and record in column 7 the values of $\Delta \mathrm{Q} / \mathrm{J}$ : If a hyphen (-) was entered in column 6 , also write a hyphen (-) in column 7; Otherwise calculate $\Delta \mathrm{Q} / \mathrm{J}$, i.e., divide the values of column 6 $(\Delta \mathrm{Q})$ between the values of column $4(\mathrm{~J})$.

9. Graph the Water Level data (H, Column 2) against the values of $\Delta \mathrm{Q} / \mathrm{J}$ (Column 7) on a loglog paper. Use a different symbol or convention for points corresponding to high values of $\Delta \mathrm{Q} / \mathrm{J}$.

10. Plot the Storage Curve, i.e., Water Level Vs. $\Delta \mathrm{Q} / \mathrm{J}$ : the storage curve must be very close to those points corresponding to high values of $\Delta \mathrm{Q} / \mathrm{J}$. The maximum value of $\Delta \mathrm{Q} / \mathrm{J}$ is generally just above the bank full level of the channel section; $\Delta \mathrm{Q} / \mathrm{J}$ is zero when the section control is effective and again when the floodplain contains most of the total discharge.

11. Read from the storage curve (Level Vs $\Delta \mathrm{Q} / \mathrm{J}$ ) the values of $\Delta \mathrm{Q} / \mathrm{J}$ and register them in Column 8 $(\Delta \mathrm{Q} / \mathrm{J}) \mathrm{aj}$

12. Calculate and record in Column 9 the new values of $\Delta \mathrm{Q}$ (now called $\Delta \mathrm{Qaj}$ ) for all measurements (regardless of the magnitude of $\mathrm{J}$ ), as follows:

$$
\Delta Q_{a j}=\left(\frac{\Delta Q}{J}\right)_{a j} \times J
$$

13. Calculate and record in Column 10 the adjusted discharges as follows: Qaj $=\mathrm{Qm}-\Delta$ Qaj; i.e., subtract columns 3 and 9 .

14. If the two Level-Q and Level- $\Delta \mathrm{Q} / \mathrm{J}$ curves cannot be improved, continue with step 15 . If an additional trial is required, return to step 4.

15. Calculate and record in column 11 the relative difference (Rel. Dif.) Between the adjusted discharge (Qaj) and the read discharges (Qr) according to the expression:

$$
\text { Dif. Rel. }=\frac{Q_{a j}-Q_{r}}{Q_{r}} \times 100
$$

If the relative differences are acceptable, continue with step 16; otherwise, perform a new test by returning to step 4 .

16. Final test: With the data of the measured water levels during a flood in the river, calculate the corresponding discharges. If the $\mathrm{H}-\mathrm{Q}$ curve of the flood (loop) is reasonable, then the curves H-Q and $\mathrm{H}-\Delta \mathrm{Q} / \mathrm{J}$ will be the last ones plotted. Otherwise, a new trial must be carried out by returning to step 4 .

\section{Calculation of discharge based on the complex rating curve (water level variation rate method)}

1. Tabulate the hourly water level data, including date and time. 
2. Calculate the value of the variation rate of levels $(\mathrm{J})$ for each water level data. It must be taken into account that:

$\mathrm{J}>0$ when the Water Level is rising (ascending phase of the flood) and

$\mathrm{J}<0$ when the Water Level is downing (descending phase of the flood)

3. From the auxiliary curve (Level vs $\Delta \mathrm{Q} / \mathrm{J}$ ) read the value of $(\Delta Q / J)$ aj for the corresponding Level.

4. Calculate the value of $\Delta \mathrm{Q}$, according to the following expression: $\Delta \mathrm{Q}=(\Delta \mathrm{Q} / \mathrm{J})$ aj $* \mathrm{~J}$

5. For each level value read the corresponding discharge value $(\mathrm{Qr})$ of the rating curve plotted for steady regime.

6. Finally, the discharge $(\mathrm{Qm})$ for a given water level will be the discharge read from the rating curve (Qr) for steady regime plus $\Delta \mathrm{Q}$ (Eq. 3).

\section{Results And Discussion}

\subsection{Simple Rating Curve}

Figure 2 shows the simple rating curve obtained for the La Balsa station. It is observed that the slope of the line, which represents the exponent of $\left(\mathrm{H}-\mathrm{H}_{0}\right)$, is less than 2.0, which indicates that there is a channel control for the H-Q relationship; i.e., the relationship is determined by the characteristics of the stretch of the river downstream of the station, such as roughness, slope and shape and size of the section of the main channel.

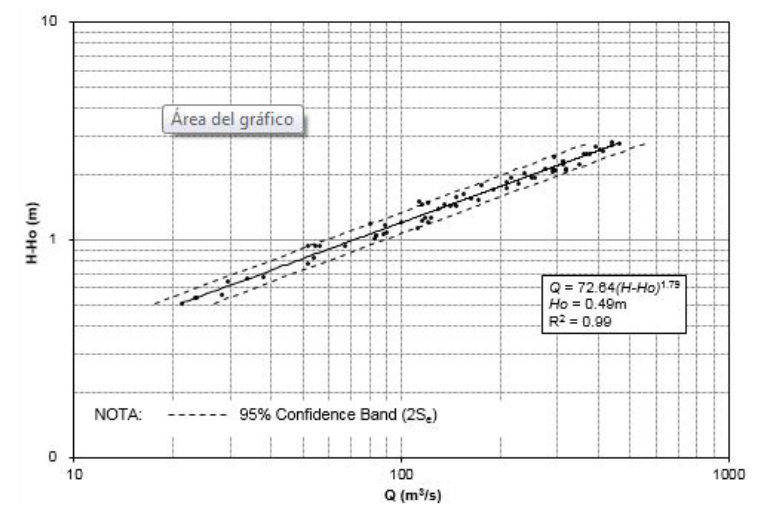

Figure 2. Water level variation in La Balsa station. Period 1 to 5 January 1998

\subsection{Complex Rating Curve}

In order to generate the rating curves, the existing gaugings from 1999 to 2004 in the different hydrometric stations were considered. In La Balsa station there are gaugings records carried out during the ascending and descending phases of floods, as well as in steady state conditions; this allowed calculating the corresponding complex rating curve. Generally the fluctuation of the water level during gaugings is important.

Table 1 shows the calculations made to determine the complex rating curve in La Balsa station through the Water Levels Variation Rate Method. Because it was not possible to refine the Q-Level and $\Delta \mathrm{Q} / \mathrm{J}$ curves, no additional tests and calculations were carried out to those presented in the Table 1. As shown in this table, the number of field records available for the ascending and descending phases of floods is limited. Having a greater number of data for these two conditions, it will be possible to achieve a better adjustment of the Level-Discharge curve and the auxiliary curve Level- $\Delta \mathrm{Q} / \mathrm{J}$ and, therefore, a lower uncertainty in the discharge deduced from the water levels measured in field. Figure 3 shows the Level-Discharge curve and the auxiliary curve Level- $\Delta \mathrm{Q} / \mathrm{J}$ finally found. Table 2 shows the calculated discharges for the moderate flood of January 01 of 1999.

\subsection{Simple Curve Vs. Complex Curve}

To illustrate the differences that can occur in the estimated discharges, the two rating curves found (simple and complex) were applied for the moderate flood of January 01, 1999. In the hydrographs obtained (Figure 4), it is observed that when the simple curve (steady state) is used during the ascending phase of the flood the discharges are underestimated (with respect to the real situation, i.e., using the complex curve), and when the water levels descend the discharges are overestimated. For the evaluated flood, the calculated discharge using the two rating curves obtained can differ up to about $19 \%$. For more intense floods the differences could be greater. 
Table 1. Determination of the complex rating curve through the water level variation rate method $(\triangle Q / J)$. Station: The: La Balsa

\begin{tabular}{|c|c|c|c|c|c|c|c|c|c|c|}
\hline Column & Column & Column & Column & Column & Column & Column & Column & Column & Column & Column \\
\hline 1 & 2 & 3 & 4 & 5 & 6 & 7 & 8 & 9 & 10 & 11 \\
\hline $\begin{array}{c}\text { Gauging } \\
\text { No. }\end{array}$ & $\begin{array}{c}H \\
(\mathbf{m})\end{array}$ & $\begin{array}{c}Q_{m} \\
\left(\mathbf{m}^{3} / \mathbf{s}\right)\end{array}$ & $\begin{array}{c}J \\
(\mathrm{~m} / \mathrm{h})\end{array}$ & $\begin{array}{c}Q_{r} \\
\left(\mathbf{m}^{3} / \mathbf{s}\right)\end{array}$ & $\begin{array}{c}\Delta \mathbf{Q} \\
\left(\mathbf{m}^{3} / \mathbf{s}\right)\end{array}$ & $\begin{array}{c}\Delta \mathbf{Q} / \mathbf{J} \\
\left(\mathbf{m}^{3} / \mathbf{s} /\right. \\
\mathbf{m} / \mathbf{h})\end{array}$ & $\begin{array}{c}(\Delta Q / J) \\
\left(\mathbf{m}^{3} / \mathbf{s} /\right. \\
\mathbf{m} / \mathbf{h})\end{array}$ & $\begin{array}{c}(\Delta Q / J)_{a j}{ }^{*} J \\
\left(\mathrm{~m}^{3} / \mathbf{s}\right)\end{array}$ & $\begin{array}{c}Q_{a j} \\
\left(\mathbf{m}^{3} / \mathbf{s}\right)\end{array}$ & $\begin{array}{c}\text { Rel. Dif. } \\
(\%)\end{array}$ \\
\hline 1 & 1.04 & 23.65 & -0.09 & 27.55 & -3.90 & 42.62 & 31.00 & 2.84 & 26.49 & 3.86 \\
\hline 2 & 1.03 & 23.42 & -0.14 & 26.87 & -3.45 & 25.16 & 30.00 & 4.12 & 27.54 & 2.47 \\
\hline 3 & 1.15 & 33.87 & -0.05 & 35.69 & -1.82 & 34.73 & 35.00 & 1.83 & 35.70 & 0.04 \\
\hline 4 & 1.42 & 52.01 & -0.18 & 61.38 & -9.37 & 53.09 & 47.00 & 8.30 & 60.31 & 1.75 \\
\hline 5 & 1.27 & 51.93 & -0.13 & 46.53 & 5.40 & -41.26 & 42.00 & 5.49 & 57.42 & 23.40 \\
\hline 6 & 1.43 & 56.12 & -0.20 & 62.50 & -6.38 & 32.52 & 47.50 & 9.32 & 65.44 & 4.70 \\
\hline 7 & 1.96 & 120.10 & -0.26 & 141.41 & -21.31 & 81.49 & 63.00 & 16.48 & 136.58 & 3.42 \\
\hline 8 & 2.51 & 236.93 & -0.30 & 266.46 & -29.53 & 98.19 & 78.00 & 23.46 & 260.39 & 2.28 \\
\hline 9 & 1.54 & 83.78 & 0.49 & 76.24 & 7.54 & 15.28 & 51.00 & -25.15 & 58.63 & 23.11 \\
\hline 10 & 1.70 & 100.21 & 0.09 & 97.47 & 2.74 & 29.88 & 55.00 & -5.03 & 95.18 & 2.36 \\
\hline 11 & 1.67 & 109.82 & 0.08 & 93.83 & 15.99 & 203.74 & 54.00 & -4.24 & 105.58 & 12.52 \\
\hline 12 & 1.62 & 111.64 & 0.26 & 86.12 & 25.52 & 96.37 & 53.00 & -14.03 & 97.61 & 13.34 \\
\hline 13 & 2.42 & 256.80 & 0.37 & 242.67 & 14.13 & 37.92 & 75.00 & -27.95 & 228.85 & 5.70 \\
\hline 14 & 2.57 & 318.02 & 0.20 & 283.08 & 34.94 & 173.16 & 81.00 & -16.34 & 301.68 & 6.57 \\
\hline 15 & 1.00 & 21.38 & 0.00 & 25.23 & - & - & 29.80 & 0.00 & 21.38 & 15.25 \\
\hline 16 & 1.05 & 28.20 & 0.00 & 28.59 & - & - & 31.01 & 0.00 & 28.20 & 1.35 \\
\hline 17 & 1.37 & 56.59 & 0.00 & 56.50 & - & - & 46.20 & 0.00 & 56.59 & 0.15 \\
\hline 18 & 1.54 & 83.94 & 0.00 & 76.24 & - & - & 51.00 & 0.00 & 83.94 & 10.09 \\
\hline 19 & 1.56 & 87.92 & 0.00 & 78.16 & - & - & 51.30 & 0.00 & 87.92 & 12.49 \\
\hline 20 & 1.56 & 89.59 & 0.00 & 78.81 & - & - & 51.30 & 0.00 & 89.59 & 13.68 \\
\hline 21 & 1.61 & 90.98 & 0.00 & 84.76 & - & - & 53.00 & 0.00 & 90.98 & 7.33 \\
\hline 22 & 1.60 & 92.59 & 0.00 & 84.09 & - & - & 52.00 & 0.00 & 92.59 & 10.11 \\
\hline 23 & 1.99 & 113.13 & 0.00 & 146.08 & - & - & 64.00 & 0.00 & 113.13 & 22.56 \\
\hline 24 & 1.95 & 115.16 & 0.00 & 139.57 & - & - & 62.00 & 0.00 & 115.16 & 17.49 \\
\hline 25 & 1.76 & 125.09 & 0.00 & 107.34 & - & - & 56.00 & 0.00 & 125.09 & 16.54 \\
\hline 26 & 1.92 & 144.23 & 0.00 & 134.14 & - & - & 62.00 & 0.00 & 144.23 & 7.52 \\
\hline 27 & 2.10 & 155.55 & 0.00 & 168.75 & - & - & 66.00 & 0.00 & 155.55 & 7.82 \\
\hline 28 & 2.03 & 163.28 & 0.00 & 154.71 & - & - & 62.20 & 0.00 & 163.28 & 5.54 \\
\hline 29 & 2.01 & 171.99 & 0.00 & 150.84 & - & - & 62.10 & 0.00 & 171.99 & 14.02 \\
\hline 30 & 2.98 & 366.64 & 0.00 & 413.59 & - & - & 118.00 & 0.00 & 366.64 & 11.35 \\
\hline 31 & 2.97 & 374.74 & 0.00 & 410.05 & - & - & 117.50 & 0.00 & 374.74 & 8.61 \\
\hline
\end{tabular}




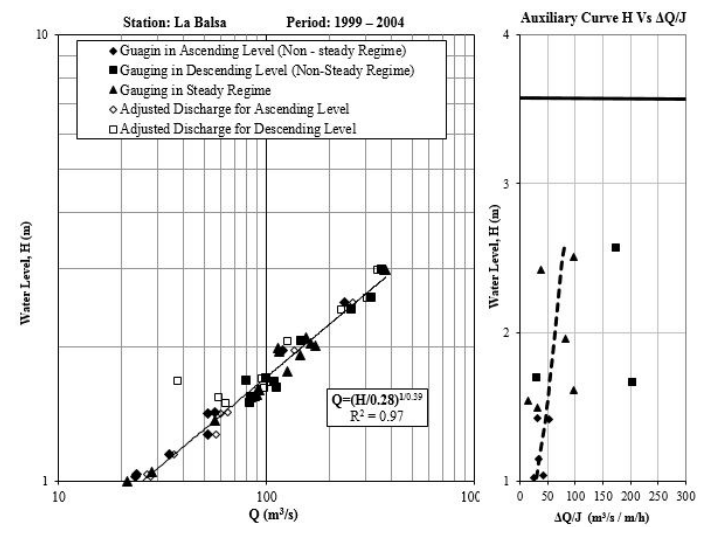

Figure 3. Rating curve Level - Discharge in steady state condition. Water level variation rate method $\Delta Q / J$

Table 2. Calculation of discharges for a flood through the method of storage per unit of variation rate of water levels ( $(Q / J)$ Station: La Balsa Date: January 1, 1999

\begin{tabular}{|c|c|c|c|c|c|c|}
\hline Time & $\begin{array}{c}H \\
(\mathbf{m})\end{array}$ & $\begin{array}{c}J \\
(\mathrm{~m} / \mathrm{h})\end{array}$ & $\begin{array}{c}(\Delta Q / J)_{a j} \\
\left(\mathbf{m}^{3} / \mathbf{s} / \mathbf{m h}\right)\end{array}$ & $\begin{array}{c}\Delta Q=\Delta Q / J * J \\
\left(\mathrm{~m}^{3} / \mathbf{s}\right)\end{array}$ & $\underset{\left(\mathrm{m}^{3} / \mathbf{s}\right)}{Q_{r}}$ & $\begin{array}{c}Q_{c} \\
\left(\mathrm{~m}^{3} / \mathbf{s}\right)\end{array}$ \\
\hline 06:00 & 2.20 & 0.23 & 70.00 & 15.75 & 189.23 & 204.98 \\
\hline 07:00 & 2.52 & 0.32 & 78.00 & 24.96 & 268.34 & 293.30 \\
\hline 08:00 & 2.84 & 0.32 & 103.00 & 32.96 & 364.94 & 397.90 \\
\hline $10: 00$ & 3.05 & 0.11 & 124.00 & 13.02 & 438.44 & 451.46 \\
\hline $10: 20$ & 2.91 & -0.42 & 118.00 & -49.56 & 387.96 & 3384 \\
\hline $10: 40$ & 2.77 & -0.43 & 96.00 & -40.80 & 341.20 & 300.40 \\
\hline $11: 20$ & 2.48 & -0.43 & 77.50 & -32.94 & 258.42 & 225.48 \\
\hline $12: 00$ & 2.20 & -0.43 & 69.00 & -29.33 & 189.23 & 159.91 \\
\hline $14: 00$ & 2.06 & -0.07 & 65.50 & -4.59 & 159.79 & 155.21 \\
\hline $16: 00$ & 2.04 & -0.01 & 65.00 & -0.65 & 155.83 & 155.18 \\
\hline 18:00 & 2.03 & -0.01 & 64.50 & -0.32 & 153.88 & 153.55 \\
\hline
\end{tabular}
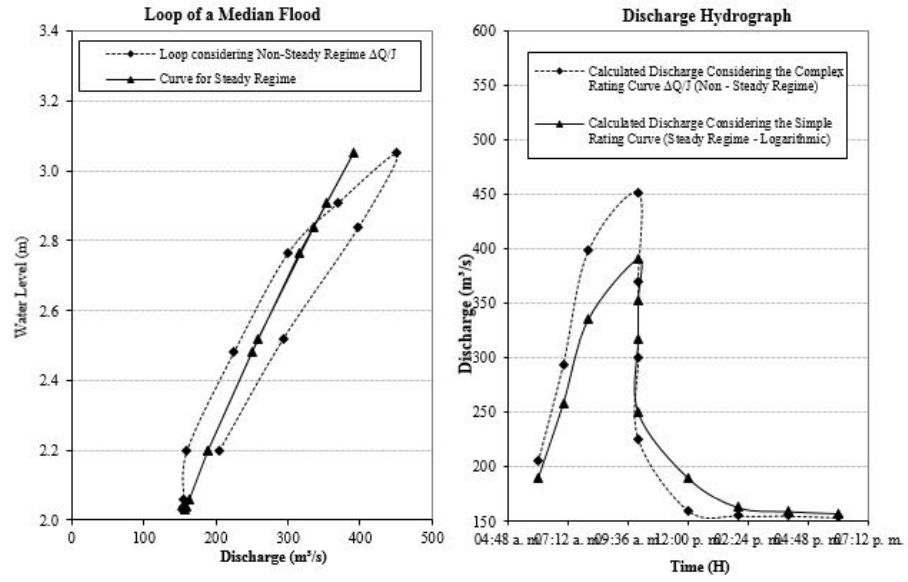

Figure 4. Determination of the discharges of a flood in the Cauca River from simple and complex rating curves. Station: La Balsa Date: January 1, 1999 


\section{Conclusions}

An important first step to obtain the rating curve in a station of a river is the analysis of the available information for the selection of the gauging data to be included in the procedure and, especially, the evaluation of the dynamics of the river to establish the type of dominant regime and the characteristics of the stretch and the natural conditions (discharge of a tributary, for example) and artificial conditions (a reservoir, a derivation, etc.) that may affect the Stage - Discharge relationship in the station.

The analysis of the variation of parameters, such as the hydraulic factor and the discharge as a function of the water level, the levels of the bed, the rates of variation of the water levels and the gradient of the free surface of water during the gauging, allows defining the characteristics of the gauging section, the type of the Stage - Discharge relationship and the procedures more appropriated to determine it. It also helps to establish the validity time of the curve.

To determine the simple rating curve in the La Balsa station, the logarithmic method was implemented because it allows identifying the type or types of control (section or channel) that determine the Stage - Discharge relationship and, therefore, extrapolate with less uncertainty the rating curve; in addition, it is easier to establish if there are changes in the type of control and, therefore, to determine with better precision the shape, curvature and tendency of the rating curve, for the different ranges of levels and in the transitions between two controls.

The operation of the Salvajina reservoir generates a dynamics of variation of water levels, depths, gradients, discharges and other parameters, which is reflected with greater intensity in the stations closest to the reservoir. This dynamic generates a complex relationship between stages and discharges (hysteresis phenomenon or process), and because of this the relationship presents a loop, indicating that for a given flood, in the same water level two different discharges occur (a higher discharge when the water level rises and a lower discharge when the water level decreases. Due to this, the Stage - Discharge relationship is complex and is conformed by the H-Q curve and an auxiliary curve that considers the different aspects that can affect it.

To find the complex rating curve in the La Balsa station (non-steady flow regime), the storage method per unit of variation rate in the levels $(\Delta Q / J)$ was implemented. This method shows significant differences in the discharges, when they are compared with those calculated using a simple rating curve (corresponding to steady regime). An example of application for the moderate flood of January 01 of 1999 shows differences of up to $19 \%$ between the discharges calculated through the two rating curves (steady and non-steady regimes).

Considering that the number of available gaugings in non-steady regime in the La Balsa station is limited, it is recommended to carry out additional gaugings both during the ascent and the descent of the water level, in order to characterize with greater detail the hysteresis phenomenon in the river and, therefore, define more accurately the auxiliary curve $\mathrm{H}$ vs. $\Delta \mathrm{Q} / \mathrm{J}$.

\section{Acknowledgments}

The authors thank the Corporación Autónoma Regional del Valle del Cauca, CVC, and the EIDENAR school of the Universidad del Valle that funded the project and the Research Groups HIDROMAR, and IREHISA of the EIDENAR school of the Universidad del Valle (Cali - Colombia ) which participated in the project.

\section{References}

1. Sivapragasam C, Muttil N. Discharge rating curve extension - A new approach. Water Resour Manag. 2005;19(5):505-20.

2. Bhattacharya DPS. Application of Artificial Neural Network in stage-discharge relationship. Proc 4-th Int Conf Hydroinformatics. 2000;4(6):184-8.

3. Deka P, Chandramouli V. A fuzzy neural network model for deriving the river stage- - discharge relationship. Hydrol Sci J [Internet]. 
2003 Apr 1;48(2):197-209. doi.org/10.1623/ hysj.48.2.197.44697

4. Kim SE, Shin J, Seo IW, Lyu S. Development of Stage-discharge Rating Curve Using Hydraulic Performance Graph Model. Procedia Engineering [Internet]. 2016;154:334-9. Available from: http://www.sciencedirect.com/ science/article/pii/S1877705816318756

5. Barbetta S, Moramarco T, Perumal M. A Muskingum-based methodology for river discharge estimation and rating curve development under significant lateral inflow conditions. Journal of Hydrology [Internet]. 2017;554:216-32. Available from: http://www.sciencedirect.com/ science/article/pii/S0022169417306261

6. Schmidt A., B.CYen. Stage-Discharge Relationship in Open Channels. Proc 2001 Int Symp Environ Hydraul. 2001;(March):81-7.

7. León JG, Calmant S, Seyler F, Bonnet MP, Cauhopé M, Frappart F, et al. Rating curves and estimation of average water depth at the upper Negro River based on satellite altimeter data and modeled discharges. J Hydrol. 2006;328(3-4):481-96.

8. León JG, Seyler F, Calmant S, Bonnet M-P, Cauhopé M. Hydrological parameter estimation for ungauged basin based on satellite altimeter data and discharge modeling. A simulation for the Caqueta River (Amazonian Basin, Colombia). Hydrol Earth Syst Sci Discuss [Internet]. 2006;3(5):3023-59. Available from: http://www.hydrol-earth-syst-sci-discuss. net/3/3023/2006/

9. Kennedy EJ. Discharge ratings at gaging stations. In: Techniques of Water-Resources Investigations of the United States Geological Survey. WASHINGTON; 1984.

10. Aldana LA. Métodos de estimación de relaciones nivel caudal . aplicación en los sistemas en tiempo real. Jornadas sobre sistemas de ayuda a la decisión ante problemas hidráulicos e hidrológicos en tiempo real. 2002;1-14.

11. Sadeghi SHR, Mizuyama T, Miyata S, Gomi T, Kosugi K, Fukushima T, et al. Determinant factors of sediment graphs and rating loops in a reforested watershed. J Hydrol [Internet]. 2008;356(3):271-82. Available from: http:// www.sciencedirect.com/science/article/pii/ S0022169408001741

12. Lohani AK, Goel NK, Bhatia KKS. TakagiSugeno fuzzy inference system for modeling stage-discharge relationship. J Hydrol [Internet]. 2006;331(1):146-60. Available from: http://www.sciencedirect.com/science/article/ pii/S0022169406002733

13. Bhattacharya B, Solomatine DP. Neural networks and M5 model trees in modelling water level-discharge relationship. Neurocomputing [Internet]. 2005;63(Supplement C):38196. Available from: http://www.sciencedirect. com/science/article/pii/S0925231204003315

14. Ajmera T, Goyal M. Development of stagedischarge rating curve using model tree and neural networks: An application to Peachtree Creek in Atlanta. Expert Systems with Applications. 2012;39:5702-10.

15. Kashani M.H., Daneshfaraz R., Ghorbani MA., Najafi MR., Kisi O. (2015). Comparison of different methods for developing a stage-discharge curve of the Kizilirmak River. Journal of Flood Risk Management 8, 71 - 86. https:// doi.org/10.1111/jfr3.12064.

16. Zeroual A, Meddi M, Assani AA. Artificial Neural Network Rainfall-Discharge Model Assessment Under Rating Curve Uncertainty and Monthly Discharge Volume Predictions. Water Resources Management [Internet]. 2016;30(9):3191-205. Available from: https://doi.org/10.1007/s11269-016-1340-8

17. Corporación Autónoma Regional Del Valle del Cauca CVC - Universidad Del Valle. Caracterización del Río Cauca Tramo Salvajina. 2006;

18. Corporación Autónoma Regional Del Valle del Cauca CVC - Universidad Del Valle. Fichas de Estaciones Hidrométricas Operadas por CVC sobre el Río Cauca en el Tramo Pan de Azúcar - Anacaro. 2005;

19. Corporación Autónoma Regional Del Valle del Cauca CVC - Universidad Del Valle. De- 
terminación y Análisis Comparativo de Curvas de Calibración Nivel - Caudal Aplicando Diferentes Metodologías en las Estaciones Hidrométricas del Río Cauca. 2005;

20. Clarke RT, Mendiondo EM, Brusa LC. Uncertainties in mean discharges from two large South American rivers due to rating curve variability. Hydrol Sci J [Internet]. 2000 Apr 1;45(2):221-36. Available from: https://doi. org/10.1080/02626660009492321

21. Claps P, Fiorentino M, Laio F. Scale di deflusso di piena di corsi d'acqua naturali. La Dif Idraul del Territ 2003. 2003;1(1):1-11.

22. Jalbert J, Mathevet T, Favre A-C. Temporal uncertainty estimation of discharges from rating curves using a variographic analysis. Vol. 397, Journal of Hydrology - J HYDROL. 2011. 83-92 p.

23. John J, Per-Erik J, David G. Rating curve uncertainty and change detection in discharge time series: case study with 44-year historic data from the Nyangores River, Kenya. Hydrological Processes [Internet]. 2013;28(4):2509-23. Available from: https://doi.org/10.1002/hyp.9786
24. Organización Internacional para la Estandarización. Medición de Caudales en Canales Abiertos - Método Area-Pendiente. ISO 1070. ISO. 1992;2:12.

25. Organización Internacional para la Estandarización. Medición de Caudales en Canales Abiertos - Determinación de la Relación Nivel-Caudal. ISO 1100-2. ISO. 1998;3:28.

26. Pérez P. A. Métodos para Elaborar Curvas de Calibración en Cauces Aluviales. Incora, editor. Bogotá; 1969. 42 p.

27. Braca G. Stage-discharge relationships in open channels: Practices and problems. FORALPS Technical Report 11. Trento; 2008.

28. Birgand F, Lellouche G, Appelboom TW. Measuring flow in non-ideal conditions for short-term projects: Uncertainties associated with the use of stage-discharge rating curves. Journal of Hydrology [Internet]. 2013;503:186-95. Available from: http:// www.sciencedirect.com/science/article/pii/ S0022169413006525

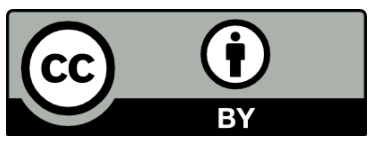

Revista Ingeniería y Competitividad por Universidad del Valle se encuentra bajo una licencia Creative Commons Reconocimiento - Debe reconocer adecuadamente la autoría, proporcionar un enlace a la licencia e indicar si se han realizado cambios. Puede hacerlo de cualquier manera razonable, pero no de una manera que sugiera que tiene el apoyo del licenciador o lo recibe por el uso que hace. 
